\title{
Freedom from Below
}

Some Introductory Thoughts*

\author{
Alice Bellagamba \\ University of Milan-Bicocca \\ alice.bellagamba@unimib.it
}

Before slavery people could have not conceived of the thing we call freedom. ${ }^{1}$

For most of human history, freedom and slavery developed as intertwined notions. ${ }^{2}$ It was only with abolition, and the subsequent waning of slavery from the daily experiences of large segments of humankind in the course of the nineteenth and early twentieth centuries, that a sense of divergence could be detected between their conceptual and experiential paths. ${ }^{3}$ Slavery morphed into the outdated manifestation of a practice on the brink of extinction, a

* The idea for this special issue was developed thanks to funding from the European Research Council in the framework of the ERC project 31373 - Shadows of Slavery in West Africa and Beyond: A Historical Anthropology. Contributors presented an earlier version of their papers at the international workshop Freedom: Bondage, Future and Selves in Central Asia, the Middle East and Africa that I organized on 17-18 Sept. 2015 at the University of Milan-Bicocca together with the ERC research team. I hereby thank all participants in the initiative, together with the university administrative staff.

1 Orlando Patterson, Slavery and Social Death (Cambridge, Mass.: Harvard University Press, 1982), 340 .

2 Luciano Canfora, Democracy in Europe:A History of an Ideology (Oxford: Blackwell Publishing, 2006), 251.

3 David Brion Davis, The Problem of Slavery in the Age of Revolution, 1770-1823 (New York: Oxford University Press, 1999). 
"uniquely intolerable moral wrong" that called for further abolitionist intervention. ${ }^{4}$ Freedom came to be considered the natural condition of human beings, ${ }^{5}$ and the fact that it kept acquiring new political, social and economic significance in relation to various kinds of severe unfreedom ${ }^{6}$ (as it had before in relation to slavery) only strengthened the progressive attitudes of abolitionist thought: the real nature of freedom was seen as the perfectible and shareable horizon of human life.

Critical theory has made a significant effort to reintegrate slavery into discourses on freedom. Baron Hesse, for instance, has argued that Western ideas of freedom have gained coherence and strength thanks to the systematic silencing of historical connections with Atlantic slave systems and European empires. ${ }^{7}$ Others have maintained that the separation between theories of freedom and the crude realities of slavery and slave trade is constitutive of the Enlightenment philosophy that was one of the matrixes of abolitionism, and out of which Western ideas about the self, rights and liberty developed. ${ }^{8}$ Upon close examination it is clear that the debates that since the second part of the twentieth century have explored the legal contours and contents of slavery are also indirect commentaries on freedom or the degrees of unfreedom deemed acceptable within notions of liberty. ${ }^{9}$ Similarly, the interest of humanities scholarship in themes such as debt, bonded labor, and the place of dependence relationships in social life betrays a concern for the fragility that the freedoms adopted by the Western world in the past century face by alternative views of sociality and politics, as well as deteriorating economic circumstances. ${ }^{10}$

4 Julia O'Connell Davidson, Modern Slavery: The Margins of Freedom (New York: Palgrave Macmillan, 2015), 8.

5 G. Prakash, "Terms of Servitude: The Colonial Discourse on Slavery and Bondage in India," in Martin A. Klein, ed., Breaking the Chains: Slavery, Bondage, and Emancipation in Modern Africa and Asia (Madison: University of Wisconsin Press, 1993), 143.

6 Norberto Bobbio, Eguaglianza e Libertà (Torino: Einaudi Contemporanea, 1995).

7 Barnor Hesse, “Escaping Liberty: Western Hegemony, Black Fugitivity," Political Theory 42, no. 3 (2014): 288-313.

Susan Buck-Morss, Hegel, Haiti and Universal History (Pittsburgh: University of Pittsburgh Press, 2009), 21-22.

Joel Quirk, "Ending Slavery in All Its Forms: Legal Abolition and Effective Emancipation in Historical Perspective," The International Journal of Human Rights 12, no. 4 (2008): 529-554; O'Connell Davidson, Modern Slavery; Jean Allain, Slavery in International Law: Of Human Exploitation and Trafficking (Leiden and Boston: Martinus Nijhoff Publishers, 2012); Marcel van der Linden and Magaly Rodríguez García, eds., On Coerced Labor: Work and Compulsion after Chattel Slavery (Leiden: Brill, 2016). 
This special issue adds to the discussion the perspective of scholars of slavery and "what lays beyond" slavery, ${ }^{11}$ which today includes varieties of unfreedom grouped within the controversial category of "new slaveries." I underline "controversial" because critics of the "new slaveries" approach are as numerous as the partisans of new abolitionism. For the former, targeting some forms of subjection and exploitation as slavery, and consequently excluding others, diverts the attention from the real object of inquiry that is the political economy of labor and capital accumulation. ${ }^{12}$ For the latter, action is possible only if the objective is clearly defined.

By using sources that range from missionary correspondence of the early nineteenth century to contemporary dossiers of asylum-seekers, the contributors to this issue adopt a bottom-up approach to valorize the point of view of the enslaved and the unfree. Mike La Rue reconstructs the quest for freedom of Halima, an early nineteenth-century Sudanese woman sold on the Cairo slave market. Elena Smolarz discusses ideas of freedom and slavery in relation to the fate of nineteenth-century enslaved Russian captives in the Imamates of Central Asia. Alice Bellagamba focuses on the struggles for emancipation and citizenship of slaves, freed slaves and slave descendants in southern Senegal from the nineteenth-century demise of the Atlantic slave trade to decolonization in the 1950s. Ehud Toledano explores the aftermath of slavery in the transition from empires to nation states in Middle Eastern and North African societies. Antonio De Lauri examines indebted Pakistani brick kilns workers, while Benjamin Lawrance deals with asylum-seekers in respectively the United Kingdom and the United States of America. John Christman's article opens up the philosophical debate on freedom to the assessment of past slaveries and the unfreedom that today is embodied by the figures of trafficked persons and bonded laborers.

"Unfree Labor," Annual Review of Anthropology 45 (2016): 451-467; James Ferguson, Give a Man a Fish: Reflections on the New Politics of Distribution (Durham, NC: Duke University Press, 2015).

11 Frederick Cooper, Thomas C. Holt, Rebecca J. Scott, "Introduction," in Frederick Cooper, Thomas C. Holt, Rebecca J. Scott, Beyond Slavery: Explorations of Race, Labor, and Citizenship in Postemancipation Societies (Chapel Hill: University of North Carolina Press, 200o).

12 Joel Quirk, The Anti-Slavery Project: From the Slave Trade to Human Trafficking (Philadelphia: University of Pennsylvania Press, 2011), 241-242; O'Connell Davidson, Modern Slavery, 3; Tom Brass, Labor Regime Change in the Twenty-First Century:Unfreedom, Capitalism, and Primitive Accumulation (Chicago: Haymarket Books, 2013). 
Each of these fascinating case studies presents its own challenges. So far scholarship on slavery in regions other than the ancient Mediterranean and the modern North Atlantic has never really placed an analysis of freedom in the foreground, partly because in most cases the end of slavery was coeval with the beginning of another form of coercion and oppression: colonialism. ${ }^{13}$ La Rue, Smolarz, Bellagamba and Toledano enrich regional literatures on slavery and emancipation with analyses of the multiple and contested ideas and practices of freedom that framed the liberation of enslaved men and women as well as the trajectories of their descendants. Similarly relevant, it is a fact that pursuing the study of freedom carries along with it a commitment to a way of doing history that destabilizes the "seeming naturalness or inevitability of the present .... in order to enable us to act - and act differently - upon it."14 Contrary to slavery, freedom "is neither past nor elsewhere; it is the historical terrain we currently inhabit, the system that governs our lives, our livelihoods, and our consciences,"15 one which has gained global currency in the world order that was born out of the Cold War, and which also has the undisputed capacity to circumscribe and conceal its uneven, unequal and violent outcomes. ${ }^{16}$ Benedetta Rossi's concluding remarks to this special issue underscore the need of assessing the economic interests and dynamics that in different historical periods have benefitted from unfreedom.

Is freedom an invention of the West? Sociologist Orlando Patterson, one of the few specialists of slavery to venture into a historical overview of this disputed notion, thought so. ${ }^{17} \mathrm{Of}$ late, however, the effort to "provincialize" these claims to exceptionality and universality has come a long way. ${ }^{18}$ Historians have traced the genealogies and diverging paths of North Atlantic and Carribean ideas of freedom, and have uncovered the patriarchal and authoritarian side

\footnotetext{
13 Cooper, Holt, Scott, "Introduction," 3.

14 David Scott, Refashioning Futures: Criticism after Postcoloniality (Princeton: Princeton University Press, 1999), 70-71.

15 Cooper, Holt, Scott, "Introduction," 3.

16 Nikolas Rose, Powers of Freedom: Reframing Political Thought (Cambridge: Cambridge University Press 1999), 61; Canfora, Democracy, 251.

17 Orlando Patterson, Freedom in the Making of Western Culture. Vol. 1 (New York: Harper Collins/Basic Books, 1992); see also Patterson, Slavery and Social Death and Craig Lambert, "The Caribbean Zola: Orlando Patterson May be the Last of Harvard Sociology's Big Thinkers," Harvard Magazine (Nov. - Dec. 2014), accessed at http://harvardmagazine.com/ 2014/11/the-caribbean-zola, 1 Feb. 2016.

18 James Laidlaw, The Subject of Virtue: An Anthropology of Ethics and Freedom (Cambridge: Cambridge University Press, 2014).
} 
of abolitionism. ${ }^{19}$ Feminist theorists have unravelled the bourgeois and male basis of liberal thought, ${ }^{20}$ while postcolonial studies assessed its imperial drive, parochial conceptions of ways of being in the world, and the consequences of applying hair-splitting discussions of Western political philosophy to societies with different political genealogies. ${ }^{21} \mathrm{~A}$ growing body of knowledge has focused on African and Asian cultural traditions of freedom, and their intersection with Western ones. ${ }^{22}$ Crucial to these discussions are issues of historicity and positionality. One of the long trends of Western philosophical thought has been to detach discussions on freedom from historical contingency in the effort to build up universal definitions that ideally encompass differences of class, gender and race. Sandra Hirschmans' feminist approach takes its cue from the idea that "the concept of freedom that liberalism has authored reflects the socio-historic conditions and concerns of the men who were doing the

19 Edmund S. Morgan, American Slavery, American Freedom: The Odyssey of Colonial Virginia (1975; reprint New York: Norton, 2003); Robert J. Steinfeld, The Invention of Free Labor: The Employment Relation in English and American Law and Culture, 1350-1870 (Chapel Hill: The University of North Carolina Press, 1991); Frank McGlynn and Seymour Drescher, eds., The Meaning of Freedom: Economics, Politics, and Culture after Slavery (Pittsburgh: University of Pittsburgh Press, 1992); Thomas C. Holt, The Problem of Freedom: Race, Labor, and Politics in Jamaica and Britain, 1832-1938 (Baltimore and London: John Hopkins University Press, 1992); Saidiya V. Hartman, Scenes of Subjection: Terror, Slavery, and SelfMaking in Nineteenth-Century America (Oxford: Oxford University Press, 1997); Eric Foner, The Story of American Freedom (New York: Norton, 1998); Rebecca J. Scott, Degrees of Freedom: Louisiana and Cuba after Slavery (Cambridge, Mass: Harvard University Press, 2009); Rebecca J. Scott and Jean M. Hébrard, Freedom Papers: An Atlantic Odyssey in the Age of Emancipation (Cambridge, Mass.: Harvard University Press, 2012); Richard Huzzey, Freedom Burning: Anti-Slavery and Empire in Victorian Britain (Ithaca: Cornell University Press, 2012); Mimi Sheller, Citizenship from Below: Erotic Agency and Carribean Freedom (Durham: Duke University Press, 2012).

20 Nancy J. Hirschmann, The Subject of Liberty: Toward a Feminist Theory of Freedom (Princeton: Princeton University Press, 2009).

21 Uday Singh Mehta, Liberalism and Empire: A Study in Nineteenth-Century British Liberal Thought (Chicago: University of Chicago Press, 1999); Partha Chatterjee, Lineages of Political Society: Studies in Postcolonial Democracy (New York: Columbia University Press, 2011).

22 Gyan Prakash, Bonded Histories: Genealogies of Labor Servitude in Colonial India (Cambridge: Cambridge University Press, 1990); David Kelly and Anthony Reid, eds., Asian Freedoms: The Idea of Freedom in East and South-East Asia (Cambridge: Cambridge University Press, 1998), 1-18; Robert Taylor, ed., The Idea of Freedom in Asia and Africa (Stanford: Stanford University Press, 2002); C.M. Cameron, "Slavery and Freedom in Small-Scale Societies," in John Bodel and Walter Scheidel, eds., On Human Bondage: After Slavery and Social Death (Chichester: John Wiley \& Sons, 2016), 210-225. 
theorizing."23 History lies at the core of experiences of freedom, not only because each historical epoch invents its own freedoms, as Marc Bloch once underlined, ${ }^{24}$ but also because the subjects of liberty are socio-historic (and gendered) constructions. ${ }^{25}$

Positionality is about cultivating a sensibility to the socio-historical roots of Western ideas of freedom, as much as understanding experiences and practices of freedom in relation to the socio-political and economic location of individuals. One example is Patterson's analysis of the ways in which the three fundamental aspects of ancient Greek freedom-liberation from somebody else's power, the capacity to act with a minimum of restraint, and equal political entitlements-differed according to status and census. Members of the ruling class took the first aspect for granted and looked with disdain at the exercise of democracy, ${ }^{26}$ while the freed slaves and resident aliens of Athens, being excluded from it, cherished precisely the political implications of freedom: "the very fact that it was the one thing that they could never hope to achieve made it all the more valuable, and an exceptional few went to great lengths to become citizens who could participate in the democratic process." 27

Political philosophy, history and the social sciences are mostly interested in the "objective" conditions of freedom, as they know the tricks of subjective perspectives. The self can experience inner forms of freedom even under the most oppressive conditions, which remain in this way undiscussed. If subjectivity, however, is meant as a dynamic connection between the "modes of perception, affect, thought, desire, fear, and so forth that animate acting subjects" and the "cultural and social formations that shape, organize, and provoke those modes of affect," 28 there is ground to explore both the individual perspective and the political and social formations that shaped it. ${ }^{29}$ Life histories are one of the strategies to zoom in on this scale of observation. This is La Rue's exper-

23 Denis Noble, Decolonizing and Feminizing Freedom: A Caribbean Genealogy (London and New York: Palgrave Macmillan, 2017), 109.

24 Marc Bloch, Apologie pour l'histoire ou métier d'historien (Paris: Librairie Armand Colin, Paris, 2e édition, 1952), 98.

25 Hirschmann, The Subject, 199-200.

26 Canfora, Democracy, 8.

27 Orlando Patterson, "The Ancient and Medieval Origins of Modern Freedom," in Steven Mintz and John Stauffer, eds., The Problem of Evil: Slavery, Freedom and the Ambiguities of American Reform (Amherst and Boston: University of Massachusetts Press, 2007), 33.

28 Sherry B. Ortner, "Subjectivity and Cultural Critique," Anthropological Theory 5, no. 1 (2005): 31 .

29 Hirschmann, The Subject, 200. 
iment through a critical assemblage of the many sources that carry a trace of Halima's existence. Thanks to Christian marriage with her owner, the French doctor Charles Dussap, Halima recovered her status as a free woman in a social context where conceptions of freedom and womanhood differed consistently from her home society. This was the beginning, rather than the end, of her quest for liberty, which she molded in relation to the socio-cultural environments that her life happened to cross. In a broader sense, such an exceptional story shows that definitions of freedom in terms of lack of external interference, of the type Western liberal thought has developed in the wake of Isaiah Berlin's seminal essay Two Ideas of Liberty (1959), ${ }^{30}$ fell short of the intricacies of real lives and of the changes that are consequential to the passing of time. In the context of slavery studies, as La Rue underlines, Halima's vicissitudes exemplify that "all the definitions of freedom slaves encountered and considered were situational, depending upon specific historical and cultural contexts, the lifestages of the enslaved individuals, and their cumulative life experiences."31

Glimpses on the enslaved point of view are also in Smolarz's contribution. Her major concern, however, is about the hazards of translation from other languages into English and French vocabularies of freedom, dependency and slavery, and the importance of historically situated analysis to approach the positionality of both academic traditions, which inspire the questions posed to the past as well as the sources used for historical reconstruction. ${ }^{32}$ If words "are our first guide to how people are thinking"33 about freedom and slavery, my contribution shows that their usages and meanings are contextual, shifting, and mutually constitutive of social and political action.

At the onset of slavery studies, Moses Finley observed that for the Greeks and the Romans, freedom was a "definable concept, and the antinomy, slave-free, a sharp, meaningful distinction. We are their heirs, and also their victims," ${ }^{34}$ as

$30 \quad$ Isaiah Berlin, Four Essays on Liberty (Oxford: Oxford University Press, 1969).

31 George Michael La Rue, "Seeking Freedom in Multiple Contexts: An Enslaved Sudanese Woman's Life Trajectory, ca. 1800-1834," in Alice Bellagamba, ed., "Freedom from Below: Enslavement, Bondage and Emancipation in Comparative Perspective," special issue of the Journal of Global Slavery 2, no. 1 (Apr. 2017): 13.

32 Stefan Hanß and Juliane Schiel, "Semantics, Practices and Transcultural Perspectives on Mediterranean Slavery," in Stefan Hanß and Juliane Schiel, eds., Mediterranean Slavery Revisited (500-1800) (Zürich: Chronos, 2014).

33 Caroline Humphrey, "Alternative Freedoms," Proceedings of the American Philosophical Society 151, no. 1 (2007): 1.

34 Moses I. Finley, "Between Slavery and Freedom," Comparative Studies in Society and History 6, no. 03 (1964): 236 . 
such antinomy has shaped the evolution of the two notions in Western culture, as well as underwritten literature and scholarship on slavery and dependency in other societies. That is why Finley suggested that scholars should distinguish among kinds of servitude "even though contemporaries were themselves not concerned to do so, at least not in their vocabulary."35 As much as the Atlantic world built upon ancient ideas of freedom and slavery, so did the Muslim one. "The Shari'a (Turkish, Şeriat) recognizes only two categories of human existence-free (Arabic, hurr) or slave ('abd)," Toledano explains, but daily realities in societies engendered hierarchies within each category: "among the enslaved, Muslim males of elite status (Turkish, $k u l$ ) ranked the highest on the social ladder, while African females populated the lowest rungs of that ladder, though legally they were all slaves."36 Post-emancipation freedoms in MENA societies built on the graded legacies of slavery, with freed black slaves and their descendants enduring lasting prejudices and discrimination under the blanket of national citizenships.

De Lauri's ethnography opens a concrete window onto the crucial theme of debt-bondage in the study of the Indian subcontinent and of the Indian Ocean. ${ }^{37}$ In line with the historiography that connects it to the rise of agricultural capitalism, he reads the experiences of kilns workers in light of the trends of labor precariousness and social uncertainty that have become globally dominant since the 1980 s. In some ways, Lawrance and Christman are equally concerned with trafficked persons. In so doing, they assess different aspects of the latest developments of North Atlantic liberal discourses on freedom and their hidden contradictions. These discourses developed against the crude realities of slavery and the slave trade. Today, borders, fences and restrictive migration policies monitor the access to those regions of the world that claim leadership in the field of freedom. Lawrance discusses the paradoxical situation of trafficked persons who have to prove their unfreedom in order to stay within

35 Finley, "Between Slavery," 235.

36 Ehud R. Toledano, "Enslavement and Freedom in Transition: MENA Societies from Empires to National States," in Alice Bellagamba, ed., "Freedom from Below: Enslavement, Bondage and Emancipation in Comparative Perspective," special issue of the Journal of Global Slavery 2, no. 1 (Apr. 2017): 110.

Alain Testart, "The Extent and Significance of Debt Slavery," Revue française de sociologie (2002): 173-204; Gwyn Campbell, ed., Abolition and Its Aftermath in the Indian Ocean Africa and Asia (London: Routledge, 2013); Gwyn Campbell and Alessandro Stanziani, eds., Bonded Labour and Debt in the Indian Ocean World (London: Routledge, 2015); Isabelle Guérin, "Bonded Labour, Agrarian Changes and Capitalism: Emerging Patterns in South India," Journal of Agrarian Change 13, no. 3 (2013): 405-423. 
the boundaries of the "free world." It is clear that in the cases described legal and government apparatuses are the causes of the marginality and vulnerability they apparently try to combat under the flag of neo-abolitionism and human rights. By exhorting to embrace the point of view of freedom-seekers rather than freedom-enjoyers, Christman participates in a reflection on the limits of Berlin's idea of negative liberty, which engaged liberal thought in the late part of the twentieth century. Critics have moved along a plurality paths in the effort to reinstate the "person and her capacity to formulate her desires, values and goals" in the debate. ${ }^{38}$ The relevant aspect for our discussion is to underline how Berlin himself was alarmed by the ready politicization of his thought "to discredit the welfare state and anything that smacked of economic regulations." ${ }^{39}$ The unfree lives De Lauri and Lawrance detail are the by-product of the late twentieth-century expansion of neo-liberal economic and social policies in all spheres of human life and to as many corners of the world as possible. In spite of its loud claims and strong partisans, this late version of freedom has no capital letter: it is only another of those "North Atlantic universals" that "appear to refer to things as they exist" but are instead "rooted in particular histories." 40

Like anthropologists, historians are "concerned with what is the case rather than what ought to be the case."41 It is their "task to insist that the discussion of freedom must transcend boundaries rather than reinforcing or reproducing them." 42 When they follow slavery and "what lays beyond" slavery, they uncover more than the historicity and positionality of this cherished notion. What comes to light are freedom's connections with privilege and its unstable relationship with equality.

38 John Christman, "Liberalism and Individual Positive Freedom," Ethics 10, no. 2 (1991): 343.

39 Eric Foner, "American Freedom in a Global Age," The American Historical Review 106, no. 1 (2001): 12.

40 Michel-Rolph Trouillot, Global Transformations: Anthropology and the Modern World (London: Palgrave, 2003), 35-36.

41 Edmund Leach, "Law as a Conditions of Freedom," in Edmund Bidney, ed., The Concept of Freedom in Anthropology (The Hague: Mouton, 1963), 76-77. 